\title{
sciendo IMPROVEMENT OF THE PRODUCTION PROCESS IN THE INDUSTRY 4.0 CONTEXT
}

doi:10.2478/mape-2018-0008

Date of submission of the article to the Editor: $04 / 2018$

Date of acceptance of the article by the Editor: 07/2018
MAPE 2018, volume 1, issue 1, pp. 55-62

\section{Dr. Sandra Grabowska \\ Silesian University of Technology, Poland}

\begin{abstract}
Dynamically changing conditions of business activity, rapid development of new technologies, increasing intensity of competition, progressing globalisation pose for entrepreneurs new, much more difficult principles than before, especially due to the increase of intensity and complexity of the environment. It is reflected in the necessity of continuous improvement of processes and their quick reorganisation.

The aim of the article is to present research conducted in metallurgical enterprise. In the article individual stages of heat treatment process, taking into consideration complications, errors and quality defects of the product arising at the stage of manufacturing the product were described. In order to minimize resulting defects, quality improvement system was implemented, using, among others Ishikawa diagram. In view of the fact that the world stands on the threshold of next industrial revolution, directions of improvement of heat treatment process in the context of Industry 4.0 were indicated.
\end{abstract}

Keywords: production process, Ishikawa diagram, Industry 4.0

\section{INTRODUCTION}

Rapidly changing business environment, development of new technologies, the increasing intensity of competition and increasing globalization pose businesses against increasingly difficult requirements (Grabowska and Furman, 2015). In contemporary, highly competitive production environment, metallurgical enterprises face the challenge of coping with large amount of data, quickness of making right decisions or flexibility of production processes. Especially the aspect of production flexibility is here important element, because now the nature of production is shaped by the paradigm shift from mass production to on-demand, customer-oriented production (Gerwin, 1993). Such actions result in shorter product life cycle, increased assortment of products, as well as the change of processes to processes of high efficiency and the change of devices and machines to more flexible devices and machines, taking into consideration the necessity of constant taking care of assumed quality of products (Gajdzik, 2013).

Industry 4.0 is currently one of the most frequently touched on topics among practitioners and scientists, making it the priority for many research centres and enterprises. Industry 4.0 is the fourth industrial revolution, in which it is assumed that it is a vision of intelligent factories built from intelligent cyber-physical systems. The implementation of this idea should allow to develop intelligent production systems, which besides above mentioned autonomy, will have properties of self-configuration, self-control or self-repair (Wittbrodt and Łapuńka, 2018).

The concept of Industry 4.0 covers areas which include numerous technologies and related with them paradigms. The main elements which are closely related to the idea of Industry 4.0 include so: industrial internet of things, cloud-based production, intelligent factories, cyberphysical systems or social product development (Hermann et al., 2015; Lee 2013; Lasi et al., 2014). 
In this concept production process will be further structured sequence of activities, thanks to which the consumer (user) has the possibility to obtain a product(good, service). It must be designed and organized for set objectives(which can change). It has dynamic character, which is conditioned by variability of quantitative and qualitative characteristics, material, energy and information feeds. It should serve maximizing profit of enterprise and customer satisfaction (Kagermann, 2014).

Quality management tools in the Industry 4.0 concept will gain strength and will be still intended to collect and process data in order to supervise the process striving for the best possible quality. They are designed for monitoring, analyzing, they influence processes during whole production process of given product. These tools are also designed for detection of defects and errors during processes, in products or services. They are intended to visualize data in whole life cycle of product (Wolniak and Skotnicka-Zasadzień, 2010).

Thanks to quality management tools, it is possible to analyze and evaluate, whether taken actions bring assumed effects and benefits, all in order to improve the processes of products and services. These tools are widely used in designing, monitoring and control of processes of manufacturing products and also all kinds of services (Molenda et al., 2016).

In production enterprises complications, errors and quality defects of the product occur, which arise at the stage of manufacturing product. Such problems have many consequences and affect the quality of product. Each plant with its own team of specialists strives for minimizing them. Therefore detailed research and analyses are conducted at various stages of production using appropriate tools. One of such tools is Ishikawa diagram, which gives the possibility to present graphically connections, which exist between analyzed problem and causes that underlie it (Jaskanis, 2018).

\section{CASE STUDY}

Dynamically changing environment, progressive technological development, increasing intensity of competition and threats of crisis phenomena require the development, improvement and implementation of innovative management systems (Grabowska, 2018).

Production enterprise BGH LLC in Katowice is a plant producing square and flat bars of various sizes and narrow tolerances (even in small production batches). It is a subsidiary of Boschgotthard, which is located in Germany. At enterprise BGH mainly steel coming from the plants of group of BGH Edelstahlwerke $\mathrm{GmbH}$ is processed. The most important products include: steels for turbine blades, stainless steels for production of knives, tool steels and nickel alloys. At enterprise BGH steel is hot-rolled, what takes place on large rolling mill duo in the line of flat block and continuous line. In order to carry out various kinds of heat treatment different devices consisting of heating and cooling units are available.

At production enterprise BGH production takes place in many stages. Beginning from rolling through the stage of heat treatment and ending with finisher. Heat treatment allows to improve material and to give it appropriate properties according to wishes of customer. Heat treatment is a kind of technological process, which is intended to change mechanical and physico-chemical properties in material in solid state by changing its microstructure in order to obtain appropriate properties extending the product life, for example increasing hardness, resistance to high temperature or strength, plasticity. It is controlled process (Blacha and Brzóska, 2016).

Following heat treatment procedures are applied at enterprise BGH:

- Heat improvement(hardening and tempering) - it is heat treatment process that consists in combination of hardening and tempering. In hardening material is heated to high temperature, maintained at this temperature and then quickly cooled. While tempering is final procedure, just after hardening, which gives the steel the best mechanical properties according to application. 
- Annealing - in the general sense it means a group of operations of ordinary heat treatment, thanks to which structure close to steady state is obtained in treated material (Jaskanis, 2018). Softening annealing (applied in BGH plant) is high-temperature heat treatment process aimed at softening the material as much as possible, so that material is easy to cut.

- Precipitation hardening (saturation and aging) - is a procedure combined with two consecutive heat treatment operations - saturation and aging. This is a way to strengthen materials, which uses the fact that the solubility of one component in the other component decreases with the decrease of temperature.

- Saturation - consists in heating the charge at temperature, which is above the limit of solubility in the area of single-phase solid solution and then in quick cooling it in order to freeze dissolved component and to prevent simultaneously repeated secreting component from solution

- Aging - while consists in heating the alloy (previously saturated) to lower temperature than limit temperature of solubility, heating it at this temperature and then cooling it down.

In researched enterprise it comes to complications, errors and quality defects of products arisen at the stage of manufacturing the product. Such problems have many consequences and affect the quality of product. Therefore proposal of solutions was developed to improve the quality of products. Quality improvement tool - the Ishikawa diagram was used.

Using a Ishikawa diagram, which shows inconsistencies in following areas: people, machine, method (technological process), material and management, problematic areas are defined. Short characteristic of causes and proposals of solutions are presented in tables $1-5$. Improvement of problematic areas in the aspect of transformation of enterprise to the requirements of Industry 4.0 are also proposed.

Table 1

Characteristic of causes of inconsistencies for component "people" and proposals of solution of them

\begin{tabular}{|c|c|c|}
\hline Description & Proposal of solution & $\begin{array}{c}\text { Proposal of solution } \\
\text { according to assumptions } \\
\text { of industry } 4.0\end{array}$ \\
\hline \multicolumn{3}{|c|}{ Inconsistency - amount of employees(breakthrough of shifts, in the system of shift work) } \\
\hline $\begin{array}{l}\text { At Heat Treatment Department 3- } \\
\text { shift system is in force ( } 2 \\
\text { employees per shift), what results } \\
\text { in employee turnover, } \\
\text { organizational changeability and } \\
\text { the change of habits }\end{array}$ & $\begin{array}{l}\text { At Heat Treatment Department the system } 2+1 \text { is } \\
\text { tested, namely } 2 \text { employees are dedicated to } \\
\text { supervising heat treatment processes, laying } \\
\text { material for thermal improvements and } 1 \\
\text { employee is dedicated to cutting simultaneously } \\
\text { with several saws samples for laboratory. This } \\
\text { system works perfectly, but it is proposed to keep } \\
\text { above mentioned model } 2+1 \text { on every shift. Staff } \\
\text { shortages (random, disease, holiday factors) } \\
\text { disturb the work. The model " } 2+1 \text { " clearly } \\
\text { improves whole process and can reduce the risk } \\
\text { of making mistakes during heat treatment. }\end{array}$ & $\begin{array}{l}\text { Building organizational } \\
\text { culture that ensures the } \\
\text { employees comfort of work, } \\
\text { adaptation of new work } \\
\text { models }\end{array}$ \\
\hline \multicolumn{3}{|c|}{ Inconsistency-experience of employees } \\
\hline $\begin{array}{l}\text { Heat treatment process is } \\
\text { specific, experience of employees } \\
\text { is very important here. At } \\
\text { department both employees with } \\
\text { long-term work experience as } \\
\text { well as newly employed } \\
\text { employees work. New employees } \\
\text { must demonstrate willingness to } \\
\text { acquire expertise and above all } \\
\text { experience. }\end{array}$ & $\begin{array}{l}\text { The support of experienced employees is the } \\
\text { basis for the proper implementation of procedure } \\
\text { of heat treatment. Friendly atmosphere in work is } \\
\text { important. }\end{array}$ & $\begin{array}{l}\text { Implementation of } \\
\text { development program for } \\
\text { employees (financing of } \\
\text { training courses, cyclical } \\
\text { search for possible areas of } \\
\text { employee development). }\end{array}$ \\
\hline
\end{tabular}




\begin{tabular}{|l|l|l|}
\hline \multicolumn{2}{|c|}{ Inconsistency - human } \\
\hline $\begin{array}{l}\text { Whole process, beginning from } \\
\text { planning heat treatment through } \\
\text { execution, reporting to computer } \\
\text { system, to the release of results } \\
\text { of laboratory tests is subject to } \\
\text { high probability of occurring } \\
\text { human error, such as: }\end{array}$ & $\begin{array}{l}\text { As proposal of changes can be offered: more } \\
\text { making aware of costs of made mistakes }\end{array}$ & $\begin{array}{l}\text { Implementation of } \\
\text { development program for } \\
\text { employees (financing of } \\
\text { training courses, cyclical } \\
\text { 1) incorrectly entered data from } \\
\text { the plan to computer system, } \\
\text { employee development). }\end{array}$ \\
2) inaccurate acquaintance & & \\
oneself with plan of heat & & \\
treatment & & \\
3) oversights & \\
4) material conversion & \\
\hline
\end{tabular}

Table 2

Characteristic of causes of inconsistency for component "Machine" and proposals of solution of them

\begin{tabular}{|c|c|c|}
\hline Description & Proposal of solution & $\begin{array}{c}\text { Proposal of solution } \\
\text { according to assumptions } \\
\text { of industry } 4.0\end{array}$ \\
\hline \multicolumn{3}{|c|}{ Inconsistency - gantry crane failure } \\
\hline $\begin{array}{l}\text { Seizing and temporary stop can } \\
\text { cause the delay during hardening, } \\
\text { resulting in, for example, } \\
\text { overcooling of material. }\end{array}$ & $\begin{array}{l}\text { Regular maintenance, inspections, monitoring of } \\
\text { gantry crane operation, creation of a file with } \\
\text { failures are proposed. Finally, eventually the } \\
\text { replacement of gantry crane with new gantry } \\
\text { crane. }\end{array}$ & $\begin{array}{l}\text { Modern Maintenance of } \\
\text { Operation. Tools supporting } \\
\text { maintenance operation and } \\
\text { preventative actions in } \\
\text { machine park. Algorithms } \\
\text { foreseeing failures. Remote } \\
\text { support systems. Systems of } \\
\text { management of } \\
\text { maintenance of operation } \\
\text { (CMMS, EAM). Integration } \\
\text { of machines. }\end{array}$ \\
\hline \multicolumn{3}{|c|}{ Inconsistency - Furnace failure } \\
\hline $\begin{array}{l}\text { Burner failure, possible arising } \\
\text { temperature differences of more } \\
\text { than } 15 \text { Celsius degrees - what in } \\
\text { turn causes different temperatures } \\
\text { in the zones of given furnace and } \\
\text { finally affects uneven heating of the } \\
\text { charge (material) during the } \\
\text { process. }\end{array}$ & $\begin{array}{l}\text { Immediate corrective actions should be taken, } \\
\text { failures should be reported to service } \\
\text { department. If immediate repair is not possible, } \\
\text { it is advisable to stop the process, take the } \\
\text { furnace out of operation and perform the } \\
\text { process on another efficient heat treatment } \\
\text { furnace. Consultation with technologist, } \\
\text { manager of production is recommended. }\end{array}$ & $\begin{array}{l}\text { Modern Maintenance of } \\
\text { Operation. Tools supporting } \\
\text { maintenance operation and } \\
\text { preventative actions in } \\
\text { machine park. Algorithms } \\
\text { foreseeing failures. Remote } \\
\text { support systems. Systems of } \\
\text { management of } \\
\text { maintenance of operation } \\
\text { (CMMS, EAM). Integration } \\
\text { of machines. }\end{array}$ \\
\hline \multicolumn{3}{|c|}{ Inconsistency - Legalization of pyrometer } \\
\hline $\begin{array}{l}\text { Employees of heat treatment use } \\
\text { daily pyrometers in order to control } \\
\text { the temperature of for example } \\
\text { hardened material. }\end{array}$ & $\begin{array}{l}\text { It is important that measuring devices should } \\
\text { have valid, up-to-date certifications. The } \\
\text { approvals are carried out by third parties. It is } \\
\text { important that during audits expiry dates of } \\
\text { approved devices should be checked. }\end{array}$ & $\begin{array}{l}\text { Analysis of data from } \\
\text { production - advanced } \\
\text { software for processing and } \\
\text { analyzing data. Analysis in } \\
\text { real time (EMI). Advanced } \\
\text { decision algorithms. } \\
\text { Effective presentation of } \\
\text { data. }\end{array}$ \\
\hline
\end{tabular}


Table 3

Characteristic of causes of inconsistency for component "Technological process" and proposals of solution of them

\begin{tabular}{|c|c|c|}
\hline Description & Proposal of solution & $\begin{array}{l}\text { Proposal of solution according } \\
\text { to assumptions of industry } 4.0\end{array}$ \\
\hline \multicolumn{3}{|c|}{ Inconsistency - Inaccurate preparation of material for heat treatment } \\
\hline $\begin{array}{l}\text { Employee on the basis of plan } \\
\text { of heat treatment prepares } \\
\text { material and composition of } \\
\text { charges. The furnace is loaded } \\
\text { evenly, symmetrically in relation } \\
\text { to its length and width. } \\
\text { Additionally it should be } \\
\text { inspected visually, if there are } \\
\text { any scratches, cracks or other } \\
\text { surface defects are present. } \\
\text { Material with surface defects } \\
\text { should not be hardened. For } \\
\text { softening annealing is binding } \\
\text { material in several places with } \\
\text { the wire necessary in order to } \\
\text { avoid dispersing. }\end{array}$ & $\begin{array}{l}\text { Experience and analysis of statistical data } \\
\text { (archive data file) are important in order to harden } \\
\text { the charges evenly and at the same time to } \\
\text { optimize the weight of the charge. With regard to } \\
\text { annealing material can not exceed admissible } \\
\text { weight depending on the dimension - for example } \\
\text { max. } 3 \text { tonnes for ready rolled dimension } 30 \times 30 \\
\text { mm. To avoid problem of inaccurate preparation } \\
\text { of material for heat treatment, more accurate } \\
\text { checking material before performing heat } \\
\text { treatment, observance of principles and rules on } \\
\text { the basis of experience of employees and also } \\
\text { guidelines are proposed. }\end{array}$ & $\begin{array}{l}\text { Robotization - flexible, robotized } \\
\text { production cells, "intelligent" } \\
\text { systems. Modern manufacturing } \\
\text { systems. Cooperation of robot } \\
\text { with a human being. Machines } \\
\text { ewith extended intelligence. }\end{array}$ \\
\hline \multicolumn{3}{|c|}{ Inconsistency - Planning heat treatment } \\
\hline $\begin{array}{l}\text { Each heat treatment process is } \\
\text { planned by specialist for } \\
\text { production planning } \\
\text { technologist. Course of } \\
\text { technological process is taken } \\
\text { into account (depending on the } \\
\text { species, it is necessary to } \\
\text { perform heat treatment up to } 6 \\
\text { hours or } 24 \text { hours after rolling), } \\
\text { the order resulting from the } \\
\text { deadlines confirmed to the } \\
\text { customers, the range of the } \\
\text { work of furnaces and process } \\
\text { optimization. }\end{array}$ & $\begin{array}{l}\text { Currently the control of the performed heat } \\
\text { treatment plans is carried out, various types of } \\
\text { files with the history of performed heat treatment } \\
\text { processes are kept, which finally help to plan new } \\
\text { heat treatment processes. It is important to be } \\
\text { systematic, accurate and reliable. Additional } \\
\text { training courses will certainly improve the process } \\
\text { of production planning. }\end{array}$ & $\begin{array}{l}\text { Modern manufacturing systems - } \\
\text { flexible systems enabling diverse } \\
\text { and personalized production for } \\
\text { customer. Remote visualization } \\
\text { and monitoring of course of } \\
\text { production. Unlimited integration. } \\
\text { Autonomous organization of } \\
\text { production. }\end{array}$ \\
\hline \multicolumn{3}{|c|}{ Inconsistency - inappropriate performing heat treatment } \\
\hline $\begin{array}{l}\text { On the basis of heat treatment } \\
\text { plan furnace operator enters } \\
\text { the data into the system and } \\
\text { supervises entire technological } \\
\text { process. He has a lot of } \\
\text { responsibility, because small } \\
\text { mistake can lead to large } \\
\text { losses and necessity of } \\
\text { repetitions. }\end{array}$ & $\begin{array}{l}\text { It is worth analyzing the possibility, so that the } \\
\text { employee does not have to enter manually } \\
\text { temperatures and times into the system and the } \\
\text { plan is created immediately in computer system. }\end{array}$ & $\begin{array}{l}\text { Analysis of production data - } \\
\text { advanced software for data } \\
\text { processing and analysis. Real- } \\
\text { time analysis. Advanced decision } \\
\text { algorithms. Effective data } \\
\text { presentation. }\end{array}$ \\
\hline
\end{tabular}

Table 4

Characteristic of causes of inconsistency for component „material” and proposals of solution of them

\begin{tabular}{|c|c|c|}
\hline Description & Proposal of solution & $\begin{array}{c}\text { Proposal of solution } \\
\text { according to assumptions } \\
\text { of industry } 4.0\end{array}$ \\
\hline \multicolumn{3}{|c|}{ Inconsistency - Improper preparation of production cards } \\
\hline $\begin{array}{l}\text { For each order card of such basic } \\
\text { data is created as: } \\
\text { - identification number of card } \\
\text { - number of melt } \\
\text { - number of species of steel } \\
\text { - norm }\end{array}$ & $\begin{array}{l}\text { Error can be made with assigning the charge to } \\
\text { given order. It means: the norm gives guidelines } \\
\text { in chemical composition of the minimum and } \\
\text { maximum and the employee assigns the charge } \\
\text { on his own on the basis of number of melt. The } \\
\text { proposal of improvement is so that additional }\end{array}$ & $\begin{array}{l}\text { Modern materials - modern } \\
\text { material structures. } \\
\text { Nanomaterials. Intelligent } \\
\text { materials. Integrated, } \\
\text { computational material } \\
\text { engineering. }\end{array}$ \\
\hline
\end{tabular}




\begin{tabular}{|c|c|c|}
\hline $\begin{array}{l}\text { - required heat treatment } \\
\text { - format of the charge } \\
\text { - ready dimension } \\
\text { - possible range of deviations } \\
\text { - kind of required surface } \\
\text { - required weight } \\
\end{array}$ & $\begin{array}{l}\text { program analyzing the selection of the melt to } \\
\text { specific order can be created. }\end{array}$ & \\
\hline \multicolumn{3}{|c|}{ Inconsistency - rolling mill defects } \\
\hline $\begin{array}{l}\text { Cracks, discontinuities or } \\
\text { scratches in rolling mill are } \\
\text { possible during rolling. }\end{array}$ & $\begin{array}{l}\text { Unnoticed defects during rolling can result in } \\
\text { expansion of the defect during heat treatment, } \\
\text { what finally leads to material damage and in } \\
\text { final effect repeated rolling of already different } \\
\text { material and repeated heat treatment will be } \\
\text { necessary. It leads to unnecessary costs and the } \\
\text { delay in execution of the order. More accurate } \\
\text { checking material before heat treatment, the } \\
\text { increase of new employees are proposed. }\end{array}$ & $\begin{array}{l}\text { Analysis of production data - } \\
\text { advanced software for data } \\
\text { processing and analyzing. } \\
\text { Real-time analysis. Advanced } \\
\text { algorithms ensuring the } \\
\text { maintenance of assumed } \\
\text { product quality. }\end{array}$ \\
\hline \multicolumn{3}{|c|}{ Inconsistency - logistic error } \\
\hline $\begin{array}{l}\text { The possibility of material } \\
\text { replacement, replacement of label } \\
\text { exists. }\end{array}$ & $\begin{array}{l}\text { In order to avoid possible logistic errors, it is } \\
\text { important to fit all, particular stages of production } \\
\text { and very good organization of work, including } \\
\text { interpersonal communication. For example, it is } \\
\text { important that material from rolling line should be } \\
\text { correctly described in circulation sheet and } \\
\text { marked (stamped), because it facilitates the work } \\
\text { of next department - in this case heat treatment } \\
\text { department. }\end{array}$ & $\begin{array}{l}\text { Intelligent logistics. Mobile } \\
\text { interfaces - multi-functional } \\
\text { equipment increasing } \\
\text { efficiency of communication } \\
\text { of production staff. Support } \\
\text { for Extended Reality }\end{array}$ \\
\hline
\end{tabular}

Table 5

Characteristic of causes of inconsistency for component "Management" and proposals of solution of them

\begin{tabular}{|c|c|c|}
\hline Description & Proposal of solution & $\begin{array}{l}\text { Proposal of solution according } \\
\text { to assumptions of industry } 4.0\end{array}$ \\
\hline \multicolumn{3}{|c|}{ Inconsistency - Training courses of employees } \\
\hline $\begin{array}{l}\text { The work according to } \\
\text { guidelines of instructions } \\
\text { allows to standardize the } \\
\text { regularity of performed works } \\
\text { of employees (at Heat } \\
\text { Treatment Department 3-shift } \\
\text { system is in force, what is } \\
\text { connected with rotation of } \\
\text { employees and, in a way, with } \\
\text { variability and habits). }\end{array}$ & $\begin{array}{l}\text { Currently regular training courses of employees } \\
\text { are carried out in accordance with guidelines of } \\
\text { instructions concerning heat treatment, which are } \\
\text { updated on ongoing basis. It is worth } \\
\text { considering, if training courses should not be } \\
\text { organized more often. }\end{array}$ & $\begin{array}{l}\text { Development of wide range of } \\
\text { new 'hard skills' and } \\
\text { unprecedented number of } \\
\text { changes in production process } \\
\text { means that „soft” skills will } \\
\text { become more important than } \\
\text { ever earlier. }\end{array}$ \\
\hline \multicolumn{3}{|c|}{ Inconsistency - Inappropriate identification of material } \\
\hline \begin{tabular}{|l|} 
At Heat Treatment Department \\
rolled material is marked with \\
appropriate labels by \\
employees. These labels are \\
intended to identify the species \\
of steel. are very important \\
element, because their \\
identification enables further \\
production process.
\end{tabular} & $\begin{array}{l}\text { Wrongly marked labels from the moment of } \\
\text { rolling or incorrect identification of material by the } \\
\text { employee cause that the repetition of the } \\
\text { process will be necessary in accordance with } \\
\text { correct marking. More training courses for less } \\
\text { experienced employees, laying greater } \\
\text { emphasizing by supervising persons on } \\
\text { employees responsible for labeling are proposed }\end{array}$ & $\begin{array}{l}\text { Analysis of production data - } \\
\text { advanced software for data } \\
\text { processing and analyzing. Real- } \\
\text { time analysis. Advanced } \\
\text { algorithms ensuring the } \\
\text { maintenance of assumed } \\
\text { product quality. }\end{array}$ \\
\hline \multicolumn{3}{|c|}{ Inconsistency - Non-observance of instructions guidelines } \\
\hline $\begin{array}{l}\text { In the company ISO } 9001 \\
\text { system is in force. Employees } \\
\text { are regularly trained. }\end{array}$ & $\begin{array}{l}\text { Non-observance of instructions causes arising } \\
\text { errors, organizational problems at each stage of } \\
\text { production. More frequent training courses are } \\
\text { proposed, especially for new employees. }\end{array}$ & $\begin{array}{l}\text { New model of management of } \\
\text { team of employees, sharing } \\
\text { responsibility and decisiveness } \\
\text { by superior with employees. }\end{array}$ \\
\hline
\end{tabular}




\section{CONCLUSION}

Rapidly changing business environment, development of new technologies, the increasing intensity of competition and increasing globalization pose businesses against increasingly difficult requirements (Grabowska, 2018).

Researched problem, it means the necessity of performing repeated heat treatment processes, which have negative impact on whole production process, was analyzed and evaluated on the basis of the Ishikawa diagram. Due to the fact that we are currently on the threshold on industrial revolution, solutions of the problem resulting from transformation of production enterprise BGH into factory of industrial 4.0 were proposed.

It was found that for the component „people” the most important cause of arising problem of repeated heat treatment is "human error". In order to minimize it, more breaks for employees, training courses, making employees aware of costs of made mistakes are proposed. For the component "machine" the most important incompatibilities were gantry crane failure and furnace failure. To eliminate arising failures in the future, regular maintenance of machines, the increase of number of inspections, the increase of monitoring machine operations, creation of file with failures and finally replacement of machine with new machine should occur. For "technological process" significant inconsistency was "inaccurate preparation of material for heat treatment department", in which the employee on the basis of heat treatment plan prepares the material, composition of the charges and in which it was easy to oversee material defects, as well as scratches, cracks or other surface defects. In order to eliminate this incompatibility experience of employees should be increased, the material should be checked more thoroughly before the execution of heat treatment, principles and rules should be observed on the basis of experience of employees, as well as guidelines should be followed and also the analysis of statistical data should be carried out. For the component "material" the most important inconsistency was incorrect preparation of production cards, where it is easy to confuse for example assignment of the charge. The proposal of improvement is to create additional program analysing the selection of the smelt to specific order. The most important inconsistency for the component "management" was incorrect identification of material. In order to minimize these inconsistencies, more training courses, emphasis on employees and the increase of awareness of costs of losses are proposed.

Carried out cause and effect analysis can contribute to minimizing arisen problem, it can influence better production efficiency, increase qualifications, awareness of employees with their preparation for done job.

\section{REFERENCES}

Blacha, L. and Brzóska, J. (2016). The use of the balanced scorecard in evaluating the results of the innovations implemented in metallurgical companies. Metalurgija, 55 No 3, pp. 0543-5846.

Gerwin, D. (1993). Manufacturing Flexibility: A Strategic Perspective. Manage. Sci., vol. 39, no. 4, pp.1213.

Gajdzik, B. (2013). World class manufacturing in metallurgical enterprise. Metalurgija 52 No 1, pp.131134.

Grabowska, S. (2018). Kluczowe wskażniki efektywności - stadium przypadku. Zesz. Nauk. PŚl., Org. Zarz. 2017 z. 108, pp. 105-111. [online] Available at: https://www.polsl.pl/Wydzialy/ROZ/ZN/ Documents/z\%20108/Grabowska\%20Sandra.pdf [Accessed 15 Apr. 2018].

Grabowska, S. and Furman, J. (2015). The business model of steel company - focus on the innovation. [online] Available at: http://konsystest.tanger.cz/files/proceedings/21/papers/4097.pdf [Accessed 05 May 2018].

Hermann, M., Pentek, T. and Otto B. (2015). Design Principles for Industrie 4.0 Scenarios: A Literature Review. Technische Universität Dortmund, No. 01.

Jaskanis, A. Podejmowanie decyzji - Diagram Ishikawy - Wykres ości ryby - Wykres przyczynaskutek. [online] Available at: http://www.wz.uw.edu.pl/pracownicyFiles/id17984-5.2\%20$\% 20$ Diagram\%20lshikawy.pdf [Accessed 05 May 2018].

Kagermann, H. (2014). Chancen von Industrie 4.0 nutzen. In: Bauernhansl, T., M. ten Hompel and B. Vogel-Heuser,: Industrie 4.0 in Produktion, Automatisierung und Logistik. Anwendung, Technologien und Migration, pp. $603-614$. 
Lasi, H., Fettke, P., Kemper H., Feld, T. and Hoffmann M. (2014). Industry 4.0. Business \& Information Systems Engineering 6, pp. $239-242$.

Lee, J. (2013). Industry 4.0 in Big Data Environment. German Harting Magazine, pp. 8 - 10.

Molenda, M., Hąbek, P. and Szczęśniak, B. (2016). Zarządzanie jakością w organizacji wybrane zagadnienia. Wydawnictwo Politechniki Śląskiej, Gliwice, p. 71.

Wittbrodt, P. and Łapuńka, I. (2018). Przemysł 4.0 - Wyzwanie dla współczesnych przedsiębiorstw produkcyjnych. [online] Available at: http://www.ptzp.org.pl/files/konferencje/kzz/artyk_pdf_2017/T2/t2_793.pdf [Accessed 24 Apr. 2018].

Wolniak, R. and Skotnicka-Zasadzień, B. (2010). Zarządzanie jakością dla inżynierów. In: Organizacja i Zarządzanie, Gliwice, pp. 73-75. 